\title{
ASPEK HUKUM PERLINDUNGAN PEREMPUAN DAN ANAK DALAM NIKAH SIRI
}

\author{
Rihlatul Khoiriyah \\ Pondok Pesantren Ulumul Qur'an Mangkang Semarang \\ e-mail: rihlatulkhoiriyah@yahoo.com
}

\begin{abstract}
Abstrak
Marriage that is not registered to the office of religious affairs (KUA) is considered as Siri marriage. It often occurs in the society while invites pros and cons among them. The perpetrators usually have different motivations to commit this kind of marriage. Unfortunately, marriage law does not set unequivocally about the legal status of Siri marriage. But it emphasizes the importance of registered marriage as a legal event. The registration of marriage has significance to the various events that are resulted from the marriage: the administration of population and the guarantee of civil rights for the concerned parties. The occurrence of Siri marriage will cause problems for the perpetrators and their families, both legal and social problems. Nevertheless there are positive and negative values in this marriage. So, the aspects of maslahat and madlarat should be considered in order to realize the legitimate purpose of marriage.
\end{abstract}

Perkawinan yang tidak dicatatkan di Kantor Urusan Agama (KUA) dikenal sebagai kawin siri. Perkawinan ini sering terjadi dalam masyarakat dan mengundang pro dan kontra diantara mereka. Pelaku kawin siri mempunyai berbagai ragam motivasi yang berbeda satu dengan lainnya. Sayangnya, hukum perkawinan tidak mengatur secara tegas tentang status hukum kawin siri. Hukum perkawinan hanya menekankan arti pentingnya pencatatan perkawinan sebagai sebuah peristiwa hukum. Pencatatan perkawinan ini mempunyai arti penting terhadap berbagai peristiwa yang ditimbulkan sebagai akibat adanya perkawinan baik administrasi kependudukan maupun jaminan hak-hak keperdataan bagi para pihak yang berkepentingan. Terjadinya kawin siri akan menimbulkan problematika bagi para pelakunya dan keluarganya, baik problematika hukum maupun problematika sosial. Meskipun demikian terdapat nilai positif dan negatif pada kawin siri tersebut. Oleh karena itu harus dipertimbangkan aspek maslahat dan madlarat agar perkawinan siri tersebut sesuai dengan tujuan disyari'atkannya perkawinan.

Kata Kunci: kawin siri; perlindungan hukum; perempuan; anak 


\section{A. Pendahuluan}

Akad nikah atau ikatan perkawinan tidak dapat disamakan dengan sebuah ikatan perikatan dalam hukum perdata. Akad nikah merupakan ikatan lahir batin antara seorang pria dengan seorang wanita yang menyatakan sebagai suami istri dan bertujuan untuk membentuk sebuah keluarga yang sakinah mawaddah wa rahmah diridhai oleh Allah. Ikatan lahir batin berarti bahwa hubungan pertalian erat antara suami istri tersebut tidak hanya dari aspek fisik lahiriyah semata akan tetapi juga adanya ikatan emosional batiniyyah.

Ikatan perkawinan tidak hanya untuk menghalalkan hubungan biologis (sex) semata, atau tidak hanya untuk mendapatkan keturunan semata, akan tetapi lebih dari itu yaitu untuk membina keluarga yang bahagia penuh cinta kasih, menentramkan jiwa dan berakhir dengan diperolehnya kebahagiaan lahir batin. Kebahagiaan sebagai wujud manifestasi dari kesejahteraan lahir batin warga negara merupakan salah satu tujuan Indonesia merdeka dan oleh karena itu Negara berkepentingan untuk melindungi kepentingan warga negaranya, kemudian lahirlah Undang-Undang No. 1 Tahun 1974 tentang Perkawinan serta diikuti dengan berbagai peraturan teknis di bawahnya. Perkawinan merupakan syari'at Islam. Rasulullah saw sangat menganjurkan umatnya untuk melangsungkan perkawinan bahkan orang yang tidak senang dengan perkawinan dianggap bukan umatnya. Rasulullah bersabda: "Sesungguhnya aku puasa, berbuka, shalat, tidur dan menikahi wanita. Barang siapa membenci (tidak melaksanakan) nikah berarti ia bukan umatku." Hadis ini jelas bahwa Islam mensyari'atkan adanya perkawinan sebagai sebuah ibadah. Peraturan perkawinan secara detail dalam ajaran Islam diatur lebih lanjut dalam fiqh munakahat dengan berbagai varian mazhab hukumnya.Meskipun negara telah mengatur regulasi tentang perkawinan untuk melindungi hak-hak sipil warga negaranya, nampaknya nikah siri masih menjadi alternatif pilihan sebagian masyarakat. Nikah siri ini merupakan nikah problematik. Realitas menunjukkan bahwa nikah siri ini masih banyak dan sering terjadi di masyarakat Indonesia. Berbagai alasan dikemukakan oleh para pelaku nikah siri ini. Tulisan ini bermaksud untuk mengkaji lebih jauh tentang status hukum nikah siri tersebut dan untuk mengurai problematika yang mengiringinya.

${ }^{1}$ Muhammad al-Syaukani, Nail al-Authar, Jilid III (Beirut: Dar al Fikr, 1994), h. 209. 


\section{B. Hakikat Pernikahan}

Perkawinan atau pernikahan menurut bahasa berarti al jam ıyang artinya menghimpun dan al-dzam yang berarti mengumpulkan. ${ }^{2}$ Sebutan lain perkawinan adalah at-tazwij yang terambil dari kata zawwaja yuzawwiju - tazwijan (arab) yang secara harfiah berarti mengawinkan, mencampuri, menemani, mempergauli, menyertai dan memperistri. ${ }^{3}$

Terdapat beberapa definisi perkawinan menurut istilah, di antaranya adalah

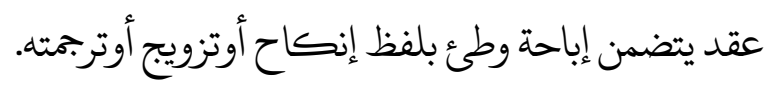

Akad yang menjamin bolehnya bersetubuh dengan lafadz inkah atau tazwij atau terjemahnya. ${ }^{4}$

Di dalam hukum perkawinan dinyatakan bahwa perkawinan merupakan ikatan lahir batin, antara seorang pria dengan seorang wanita sebagai suami istri dengan tujuan membentuk keluarga, rumah tangga yang bahagia dan kekal berdasarkan Ketuhanan Yang Maha Esa. ${ }^{5}$ Kompilasi Hukum Islam (KHI) mendefinisikan perkawinan sebagai suatu akad yang sangat kuat (mitsaqanghalidzan) untuk mentaati perintah Allah dan melaksanakannya merupakan ibadah. ${ }^{6}$ Dari beberapa definisi tersebut, penulis lebih memilih definisi yang tertuang dalam undang-undang perkawinan.

Dasar hukum disyariatkannya perkawinan adalah ayat-ayat al-Qur'an dan beberapa hadis Nabi. Firman Allah dalam al-Qur'an surat al-Nisa' ayat 3 yang artinya:

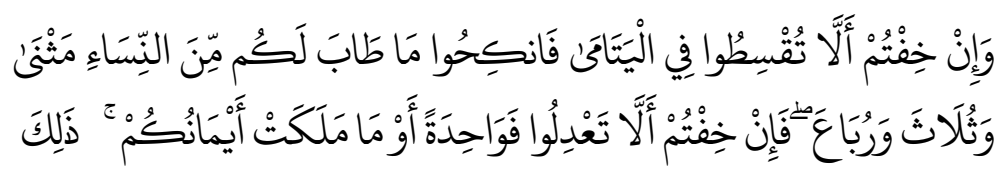

${ }^{2}$ Taqiyuddin Abu Bakar ibn Ahmad al-Husaini, Kifayatul Akhyar, Juz II, (Indonesia: Darul Thya Kutubil Arabiyah, t.th), h. 36.

${ }^{3}$ Muhammad Amin Suma, Hukum Keluarga Islam di Dunia Islam, (Jakarta: Raja Grafindo Persada, 2004), h. 43.

${ }^{4}$ Muhammad Amin al-Kurdi, Tanwir al-Qulub, (Beirut: Darul Fikr, t.th.), h. 373.

${ }^{5}$ Pasal 1 Undang-Undang No. 1 Tahun 1974 tentang Perkawinan.

${ }^{6}$ Pasal 2 Kompilasi Hukum Islam. 


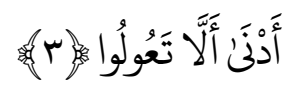

"Dan jika kamu takut tidak akan dapat berlaku adil terhadap( hak-hak) perempuan yang yatim bilamana kamu mengawininya, maka kawinilah wanita-wanita (lain) yang kamu senangi; dua, tiga atau empat. Kemudian jika kamu takut tidak dapat berlaku adil maka kawinilah seorang saja, atau budak-budak yang kamu miliki. Yang demikian itu adalah yang lebih dekat kepada tidak berbuat aniaya".

Firman Allah dalam surat al-Nur ayat 32:

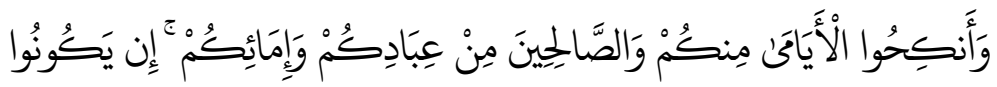

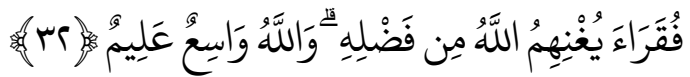

"Dan kawinkanlah orang-orang yang sendirian di antara kamu, dan orang-orang yang layak berkawin dari hamba-hamba sahayamu yang laki-laki dan hamba-hamba sahayamu yang perempuan. Jika mereka miskin Allah akan memampukan mereka dengan karunia-Nya. Dan Allah maha luas (pemberian-Nya)."

Rasulullah bersabda:

$$
\begin{aligned}
& \text { عن ابن مسعود رضي الله تعالى عنه قال: قال رسول الله صلى الله عليه وسلم: } \\
& \text { يامعشر الشباب من استطاع منكم الباءة فليتزوج فانه اغض للبصر واحصن } \\
& \text { للفرج ومن لم يستطع فعليه بالصوم فانه له وجاء. (رواه الجماعة). }
\end{aligned}
$$

Dari Ibnu Mas'ud berkata; Rasulullah bersabda, "Wahai para kaum muda barang siapa di antara kamu telah mampu akan beban nikah maka hendaklah dia menikah, karena sesungguhnya menikah itu lebih dapat memejamkan pandangan mata dan lebih dapat menjaga kemaluan. Dan barangsiapa yang belum mampu (menikah) maka hendaklah dia rajin puasa karena sesungguhnya puasa itu menjadi penahan nafsu baginya." (HR. al-Jama'ah)

${ }^{7}$ Yayasan Penyelenggara Penterjemah al-Qur'an Depag RI., al-Qu'an dan Terjemahnya, (Semarang: Toha Putra, 1989), h. 115.

${ }^{8}$ Ibid., h. 549.

${ }^{9}$ Muhammad al-Syaukani, Nail al-Authar, h. 171. 
Rasulullah bersabda:

$$
\begin{aligned}
& \text { وعن قتادة عن الحسن عن سمرة: ان الببي صلى الله عليه وسلم نهى عن } \\
& \text { التبتل, وقرأقتادة: ولقد ارسلنا رسلا من قبلك وجعلنا لهم ازواجا وذرية. }
\end{aligned}
$$

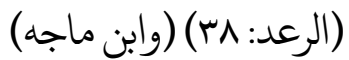

Dari Qatadahdari al-Hasan dari Samurah; Sesungguhnya Nabi melarang membujang, selanjutnya Qatadah membaca ayat. "Sesungguhnya kami telah mengutus beberapa orang Rasul sebelum kamu dan kami berikan kepada mereka beberapa istri dan anak cucu." (HR. Ibnu Majah) ${ }^{10}$

Para fuqaha berbeda pendapat tentang status hukum asal dari perkawinan menurut pendapat yang terbanyak dari fuqaha imam Syafi'i hukum nikah adalah mubah, menurut madzhab Hanafi, Maliki dan Hambali hukum nikah adalah sunnah, sedangkan menurut madzhab Dhahiri dan Ibnu Hazm hukum nikahadalah wajib dilakukan sekali seumur hidup. ${ }^{11}$ Adapun hukum melaksanakan pernikahan jika dihubungkan dengan kondisi seseorang serta niat dan akibatnya, maka tidak terdapat perselisihan di antara para ulama', bahwa hukum melaksanakan perkawinan ada lima macam yaitu: 1) Jaiz (boleh), ini asal hukumnya. 2) Sunat, bagi orang yang berkehendak serta cukup nafkah sandang, pangan, dan lain-lain. 3) Wajib, bagi orang yang cukup sandang, pangan dan dikhawatirkan terjerumus ke dalam lembah perzinaan. 4) Makruh, bagi orang yang tidak mampu memberi nafkah. 5) Haram, bagi orang yang hendak menyakiti perempuan yang akan dinikahi. ${ }^{12}$

Nilai asasi yang ingin diraih dari perkawinan adalah ketenangan, ketenteraman, dan kasih sayang. Bila ketenangan dan ketenteraman mewarnai suasana rumah tangga, maka ia akan menghasilkan manusia unggulan dan terjamin mutu. ${ }^{13}$ Hal ini senada dengan firman Allah surat al-Rum ayat 21 yaitu:

${ }^{10} \mathrm{Abi}$ Isa Muhammad Ibnu Isa Saurah, Jami'us Shahih Sunan al- Tirmidzi (Beirut: Darul Fikr, tth.), h. 467.

${ }^{11}$ Zahry Hamid, Pokok-pokok Hukum Perkawinan Islam dan UU Perkawinan di Indonesia (Yogyakarta: Bina Cipta, 1978), h. 3-4.

${ }^{12}$ Ahmad Azhar Basyir, Hukum Perkawinan Islam (Yogyakarta: UU Press, 2004), h. 14.

${ }^{13} \mathrm{Ahmad}$ Faiz, Cita Keluarga Islam (Jakarta: Serambi Ilmu Semesta, 2001), h. 26. 


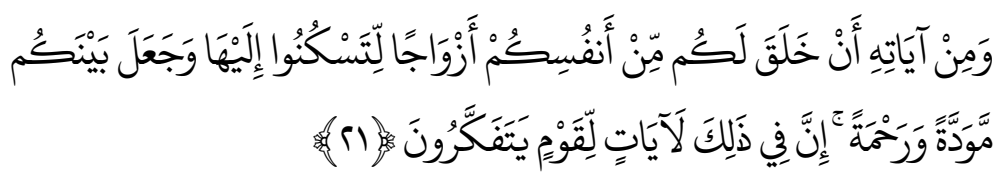

"Dan di antara tanda-tanda kekuasaan-Nya ialah Dia menciptakan untukmu istri-istri dari jenismu sendiri supaya kamu cenderung dan merasa tenteram kepada-Nya, dan dijadikannya di antaramu rasa kasih dan sayang. Sesungguhnya pada yang demikian itu benar-benar terdapat tanda-tanda bagi kaum yang berfikir." (QS. al-Rum: 21$){ }^{14}$

Berdasarkan ayat tersebut, menurut penulis terdapat lima nilai fundamental dalam perkawinan yaitu: 1) suami istri merupakan satu kesatuan yang tak terpisahkan (min anfusikum) atau dalam bahasa jawanya "sak awak", 2) ketenangan jiwa (litaskunu ilaiha), 3) cinta kasih (mawaddah) yang lebih berorientasi pada pemenuhan nafsu biologis, 4) kasih sayang (rahmah) yang lebih berorientasi pada sifat-sifat kemanusiaan sampai akhir hayatnya, dan 5) arti pentingnya berfikir (yatafakkarun) secara realistis dalam menghadapi problematika kehidupan berumah tangga tidak mengedepankan emosional.

Terdapat banyak fungsi dan tujuan dari perkawinan, di antaranya adalah: 1) Menyalurkan naluri seksual secara sah dan benar. 2) Cara paling baik untuk mendapatkan anak dan mengembangkan keturunan secara sah. 3) Menyalurkan naluri kebapakan atau keibuan. 4) Memupuk rasa tanggung jawab dalam rangka memelihara dan mendidik anak, sehingga memberikan motivasi yang kuat bagi seseorang untuk membahagiakan orang-orang yang menjadi tanggung jawabnya. Membagi rasa tanggung jawab antara suami dan istri yang selama ini dipikul masing-masing pihak. ${ }^{15}$

Perkawinan yang berkualitas merupakan harapan para pihak yang ber sentuhan langsung maupun tidak langsung dengan perkawinan tersebut. Suatu perkawinan dianggap berkualitas apabila nilai asasi atau nilai fundamental dalam perkawinan dapat terwujud dalam kehidupan berumah tangga. h. 644 .

${ }^{14}$ Yayasan Penyelenggara Penterjemah al-Qur'an Depag RI., al-Qu'an dan Terjemahnya,

${ }^{15}$ Abdul Aziz Dahlan, Ensiklopedi Hukum Islam (Jakarta: PT. Intermasa, 1996), h. 1329. 


\section{Pengertian Nikah Siri}

Terminologi nikah siri tidak ditemukan di dalam hukum perkawinan maupun dalam fiqh munakahat klasik. Untuk mengetahui pengertian nikah siri ini maka dapat ditelusuri dari pengertian etimologis kata nikah dan kata siri. Kata nikah dapat diidentikkan dengan perkawinan atau pernikahan. Oleh karena itu pengertian kata nikah ini identik dengan pengertian perkawinan atau pernikahan yang lazim terdapat dalam literatur fiqh munakahat maupun hukum perkawinan. Sedangkan kata siri (bahasa Arab; jamak asrar) mempunyai pengertian rahasia, sembunyi-sembunyi, mistri, dengan diam-diam, tertutup, dan gundik ${ }^{16}$.

Yang dimaksud dengan nikah siri menurut penulis adalah sebuah akad nikah atau perkawinan yang telah memenuhi segala persyaratan dan rukun nikah, akan tetapi peristiwa perkawinan tersebut tidak dicatatkan di lembaga pencatat perkawinan atau Kantor Urusan Agama (KUA), dan terkadang lebih parah lagi yang mengetahui adanya nikah siri tersebut hanya beberapa orang yang terlibat secara langsung. Jadi nikah siri juga harus melalui tahapan prosesi akad nikah seperti lazimnya perkawinan pada umumnya, tapi akad nikahnya tidak dicatatkan di lembaga resmi. Orang yang akan melangsungkan nikah siri harus memenuhi berbagai syarat dan rukun sebagaimana telah diatur dalam fiqh munakahat. Yang dijadikan pedoman para pelaku nikah siri hanya literatur kitab-kitab klasik, dan mengabaikan proses administratif sebagaimana yang telah diatur dalam hukum perkawinan dan peraturan tekhnis di bawahnya. Oleh karena itu pelaku nikah siri tidak mempunyai akta nikah.

Ada beberapa nama lain dari nikah siri ini yang dikenal di masyarakat, di antaranya adalah kawin siri, nikah syara', nikah kyai, kawin bawah tangan, kawin diam-diam, kawin rahasia, dan kawin lari. Nikah siri sebagaimana yang dimaksudkan dalam pengertian tersebut di atas pada prinsipnya sama dengan perkawinan pada lazimnya. Ketika melangsungkan nikah siri, semua syarat rukun perkawinan harus telah dipenuhi. Calon suami, calon istri, wali, ijab qabul, dan para saksi telah dipersiapkan dan telah memenuhi persyaratan substantif syari'at Islam. Di dalam syari'at Islam, pencatatan perkawinan oleh

${ }^{16}$ Ahmad Warson Munawir, Kamus al-Munawir (Yogyakarta: Pondok Pesantren alMunawir, 1984), h. 667-668. 
petugas tidak termasuk syarat rukun perkawinan. Olehkarenaitumenurutpenulis, ada atau tidak adanya pencatatan perkawinan tidak mempengaruhi sah atau tidak sah suatu perkawinan. Sah atau tidak sah perkawinan hanya diukur dari aspek terpenuhinya syarat rukun substantif perkawinan yang meliputi calon suami, calon istri, wali, ijab qabul, dandua orang saksi. Nikah siri yang telah memenuhi syarat rukun substantif nikah maka status hukumnya adalah sah. Apabila di kemudian hari diadakan pencatatan di Kantor Urusan Agama (KUA) maka tidak memerlukan lagi akad nikah yang baru.

Perkawinan merupakan sebuah peristiwa hukum dan oleh karena itu pencatatan perkawinan mempunyai arti yang sangat penting untuk mengantisipasi berbagai kemungkinan permasalahan yang akan muncul di kemudianhari. Meskipun secara tekstual tidak ada ketentuan pencatatan perkawinan dalam nash al-Qur'an atau hadis, pencatatan perkawinan ini dapat diqiyaskan dengan pencatatan transaksi utang piutang (dain) sebagaimana terekam dalam al-Qur'an surat al-Baqarah ayat 282 (faktubuh, walyaktub bainakum katibunbil 'ad).

Tujuan pencatatan perkawinan juga untuk mewujudkan kemaslahatanbagi para pihak yang terlibat dalam perkawinan serta anak-anak juga keluarga mereka dan menghindari mafsadat (kemungkinan terburuk) minimal berupa fitnah. Maslahat dan mafsadat pencatatan perkawinan ini bersifat personal danrelatif tergantung situasi dan kondisi yang bersangkutan. Berdasarkan kaidah ushul fiqh dar ulmafasid muqaddamun 'ala jalbil mashalih (menghindarikemungkinanterburuk yang menyebabkan kerusakan harus didahulukan daripada menarik maslahat), maka para pelaku perkawinan harus berfikir secara jernih danbertanggungjawabuntuk tidak mencatatkan perkawinan mereka. Jadi, menurut penulis pencatatan perkawinan harus dilaksanakan dan hukumnya wajib meskipun tidak mempengaruhi sahnya perkawinan.

Pelaku nikah siri tidak memerlukan dokumen-dokumen kelengkapan administratif dari kelurahan, kecamatan atau Kantor Urusan Agama (KUA) setempat. Yang menjadi ciri khas utama nikah siri adalah tidak adanya pencatatan nikah oleh Pegawai Pencatat Nikah (PPN) dan tidak ada bukti administratif yang autentik telah terjadinya perbuatan hukum berupa perkawinan. Oleh karena itu para pelaku nikah siri tidak mempunyai akta nikah yang dapat dijadikan sebagai alat bukti yang sah terhadap perkawinan mereka. Di hadapan hukum mereka akan kesulitan untuk membuktikan bahwa mereka telah me- 
nikah. Karena adanya kesulitan pembuktian seperti ini maka akan memunculkan fitnah kepada para pelaku, keluarga dan juga anak-anak yang dilahirkan dari pernikahan siri tersebut. Pembuktian perkawinan ini juga diperlukan dalam pengurusan dokumen administrasi kependudukan setiap warga negara.

Di dalamPasal 2 Undang-Undang No. 1 Tahun 1974 tentang Perkawinan dinyatakan bahwa perkawinan adalah sah apabila dilakukan menurut hukum masing-masing agamanya dan kepercayaannya. Berdasarkan ketentuan ini maka nikah siri yang telah memenuhi syarat rukun sebagaimana diatur dalam fiqh munakahat maka perkawinan mereka adalah sah menurut ajaran agama dan juga sah menurut undang-undang perkawinan yang berlaku di Indonesia. Pencatatan perkawinan merupakan aturan yang sifatnya administratif, dan tidak ada sanksi hukum bagi mereka yang tidak mencatatkan perkawinannya. Perkawinan yang tidak dicatatkan ini tidak mempunyai kekuatan hukum, sehingga akan merugikan para pihak yang berkepentingan apabila diperlukan bukti-bukti administratif telah terjadinya perkawinan tersebut di kemudian hari.

\section{Faktor Penyebab dan Problematika Nikah Siri}

Terjadinya nikah siri di masyarakat merupakan sebuah fenomena atau realitas sosial dan tentu ada alasan-alasan atau motifasi dari para pelakunya. Di antara alasan-alasan para pelaku melakukan nikah siri ini, menurut penulis antara lain adalah pertama para pelaku nikah siri tidak bisa atau kesulitan memenuhi persyaratan administratif yang disyaratkan oleh undang-undang perkawinan atau peraturan teknis di bawahnya. Misalnya calon mempelai yang belum mencapai usia batas syarat nikah yaitu 16 tahun bagi wanita dan 19 tahun bagi pria. ${ }^{17}$ Setelah melakukan upaya dispensasi kawin di Pengadilan Agama (PA) tidak berhasil, kemudian mereka melakukan nikah siri sebagai alternatif terakhir. Ada juga yang karena menunggu proses cerai di Pengadilan Agama (PA) yang berlarut-larut ${ }^{18}$, nikah siri menjadi alternatif ketika akan melangsungkan perkawinan lagi.

${ }^{17}$ Lihat ketentuan Pasal 7 Undang-Undang Nomor 1 Tahun 1974.

${ }^{18}$ Sebelum ada putusan cerai dari PA, pihak suami atau istri sudah meyakini bahwa talak pada hakekatnya sudah jatuh sekian bulan yang lalu (talak kinayah atau sharih) terhitung sejak suami menyatakan thalak, dan telah lewat masa iddahnya bagi wanita. 
Kedua, para pelaku nikah siri terbentur dengan persyaratan administratif atau aturan kepegawaian sebagai Pegawai Negeri Sipil (PNS), TNI, POLRI, pegawai perusahaan swasta tertentu atau pensiunan. Para pelaku (janda atau duda pensiunan) sengaja menyembunyikan perkawinan mereka (dengan nikah siri) agar tunjangan pensiun tidak berhenti. Para pelaku juga menyembunyikan perkawinan mereka (dengan nikah siri) agar mereka tidak dikeluarakan dari perusahaan tempat mereka bekerja, dan lain sebagainya. Nikah siri sebagai 'penyelamat' keadaan yang amat darurat.

Ketiga, nikah siri sebagai penutup aib yaitu untuk menutupi rasa malu di masyarakat karena ternyata diketahui anak gadisnya sudah hamil terlebih dahulu, atau mungkin sudah terlanjur melahirkan. Orang tua atau wakilnya biasanya menginformasikan kepada masyarakat (ketika ada upacara walimah arus) bahwa anaknya sudah nikah siri beberapa bulan yang lalu, dan sekarang baru sempat mengurus administratif perkawinan di KUA setempat.

Keempat, nikah siri sebagai alternatif poligami untuk 'mengamankan' bangunan rumah tangga dengan istri sebelumnya. Bangunan rumah tangga dengan istri terdahulu akan tetap kokoh dan aman, sementara suami kawin lagi dengan wanita idamannya dengan cara nikah siri tanpa diketahui oleh istri atau keluarga istri terdahulu. Jadi nikah siri dijadikan sebagai alternatif pahlawan penolong bagi mereka yang suka poligami dengan memiliki istri simpanan ${ }^{19}$ yang sah menurut agama.

Kelima, nikah siri sebagai upaya tindakan prefentif untuk menghindari dosa atau zina bagi para pasangan muda mudi yang sedang berpacaran. Di suatu daerah tertentu yang ajaran atau keyakinan agamanya sangat kuat, ketika ada khitbah (lamaran) biasanya ada yang langsung menikahkan anak mereka dengan cara nikah siri terlebih dahulu. Mereka takut kalau anak mereka terjerumus dosa, dan beberapa bulan atau beberapa tahun kemudian baru dilangsungkan 'perkawinan negara' atau 'perkawinan resmi'.

Terdapat beberapa dampak negatif (mafsadat) yang diakibatkan oleh nikah siri. Di antara dampak negatif tersebut adalah anak yang dilahirkan dari nikah siri akan menjadi korban. Permasalahan anak yang dilahirkan dari nikah siri ini di

${ }^{19}$ Dalam fiqh munakahat, suami yang akan berpoligami tidak memerlukan syarat persetujuan dari istri sebelumnya. 
antaranya adalah pertama, biasanya anak tersebut menemukan kesulitan dalam pengurusan dokumen administrasi kependudukan. Kedua, tidak adanya jaminan terpenuhinya hak-hak sipil sebagai anak. Ketiga, secara keperdataan anak tersebut hanya mempunyai nasab kepada ibu atau keturunan ibu, meskipun secara syar $i$ anak tersebut mempunyai bapak. Jadi status anak tersebut dianggap sebagai anak dari seorang ibu yang tidak mempunyai suami. ${ }^{20}$

Wanita yang dinikah siri juga terkadang menjadi korban. istri tidak mendapatkan perlindungan hukum atas status perkawinan mereka, apabila hak-hak istri diabaikan oleh suami maka ia tidak dapat memperjuangkan hak-haknya melalui jalur hukum. Istri yang dinikah siri akan sangat terpukul apabila ternyata suaminya tidak bertanggungjawab dan hanya 'menikmati sesaat' atas perkawinan mereka, habis manis sepah dibuang. Belum lagi status istri yang diceraikan dari nikah siri ini. Secara lahiriyah sudah tidak gadis lagi atau janda, tetapi ia tidak mempunyai bukti pernah melangsungkan perkawinan atau sudah cerai.

Dari beberapa paparan tersebut di atas, nampak jelas bahwa nikah siri merupakan perkawinan yang problematik dan dampak negatifnya sangat besar meskipun diakui ada juga nilai positif atau maslahatnya sebagaimana telah dipaparkan di atas.

\section{E. Kesimpulan}

Nikah siri masih banyak dan sering terjadi di masyarakat. Hukum perkawinan tidak mengatur secara tegas tentang status hukum nikah siri. Nikah siri yang telah memenuhi semua syarat rukun perkawinan dalam fiqh munakahat hukumnya adalah sah. Hukum perkawinan menekankan arti pentingnya pencatatan perkawinan sebagai sebuah alat bukti peristiwa hukum dan bersifat administratif. Pencatatan perkawinan ini akan memberikan jaminan perlindungan hukum bagi para pihak yang melangsungkan perkawinan dan juga anak dan keluarga.

Terjadinya nikah siri akan menimbulkan problematika bagi para pelakunya dan keluarganya, baik problematika hukum maupun problematika sosial.

${ }^{20}$ Dalam konteks perlindungan anak, maka pelaku kawin siri yang melahirkan anak dan mengakibatkan penelantaran anak sehingga anak menderita fisik, mental maupun sosial dapat dipidana 5 tahun. Lihat ketentuan Pasal 77 UU No. 23 Tahun 2002 tentang Perlindungan Anak. 
Terdapat nilai positif dan negatif pada kawin siri tersebut. Harus dipertimbangkan aspek maslahat dan madlarat agar nikah siri tersebut tidak menyimpang dari tujuan disyari atkannya perkawinan.]

\section{Daftar Pustaka}

Basyir, Ahmad Azhar, Hukum Perkawinan Islam, Yogyakarta: UU Press, 2004.

Dahlan, Abdul Aziz, Ensiklopedi Hukum Islam, Jakarta: PT. Intermasa, 1996.

Faiz, Ahmad, Cita Keluarga Islam, Jakarta: Serambi Ilmu Semesta, 2001.

Hamid, Zahry, Pokok-pokok Hukum Perkawinan Islam dan UU Perkawinan di Indonesia, Yogyakarta: Bina Cipta, 1978.

al-Husaini, Taqiyuddin Abu Bakar Bin Ahmad, Kifayatul Akhyar, Juz II, Indonesia: Darul Thya Kutub al-Arabiyah, tth.

Munawir, Ahmad Warson, Kamus al-Munawir, Yogyakarta: Pondok Pesantren Al-Munawir, 1984

Kompilasi Hukum Islam.

al-Kurdi, Muhammad Amin Tanwir al-Qulub, Beirut: Darul Fikr, t.th.

Saurah, Abi Isa Muhammad ibn Isa, Jami'us Shahih Sunan al-Tirmidzi, Beirut: Darul Fikr, t.th.

Suma, Muhammad Amin, Hukum Keluarga Islam di Dunia Islam, Jakarta: Raja GrafindoPersada, 2004.

al-Syaukani, Muhammad, Nail al Authar, Jilid III, Beirut: Dar al Fikr, 1994.

Undang-Undang No. 1 Tahun 1974 tentang Perkawinan.

Undang-Undang No. 23 Tahun 2002 tentang Perlindungan Anak.

Yayasan Penyelenggara Penterjemah al-Qur'an, Al-Qu'an dan Terjemahnya, Semarang: Toha Putra, 1989. 